\title{
Effects of ultraviolet radiation on production of photoprotective compounds in microalgae of the genus Pediastrum from high Andean areas of Peru
}

\author{
Cecil Tenorio $^{1 *}$ (D), Jorman Alexander Henriquez Ramírez² (D), Leenin Flores Ramos ${ }^{1}$ (D), Anthony Ruiz Soto ${ }^{1}$ (D), \\ Jessie $\operatorname{Vargas}^{2}$ \\ 'Instituto del Mar del Perú (IMARPE), Banco de Germoplasma de Organismos Acuáticos \& Laboratorio de Análisis Instrumental, Callao, Peru. \\ ${ }^{2}$ Universidad Nacional Agraria la Molina, Facultad de Pesquería, Lima, Perú.
}

\section{ARTICLE INFO \\ Received on: 22/07/2021 \\ Accepted on: 09/10/2021 \\ Available Online: 05/03/2022 \\ Key words: \\ Pediastrum, antioxidant \\ activity, pigments, \\ polyphenols, lutein, cosmetic.}

\begin{abstract}
This study aims to collect microalgae from high Andean areas and evaluate their potential as natural ingredients in the cosmetics industry. The cell growth, pigment concentration, antioxidant activity, and polyphenols content of two microalgae of the genus Pediastrum (IMP-BG288 and IMP-BG255) collected from high Andean lagoons of more than 3,000 m.a.s.l. (Ayacucho, Peru) were evaluated. The cultures were exposed to photosynthetically active radiation (PAR) (400-700 nm) and PAR with ultraviolet radiation A and B (PAB) (280-700 nm) in 21 photobioreactors. Cultures of the genus Pediastrum sp. subjected to PAB radiation showed greater growth until the sixth day, when they reached the end of their exponential phase. The maximum concentrations of lutein and chlorophyll a and $\mathrm{b}$ were 6.96 $\pm 0.21,1.64 \pm 0.05$, and $0.84 \pm 0.06 \mathrm{mg} / \mathrm{g}$, respectively; total antioxidant activity and total polyphenol content were $221.7 \pm 11.76 \mu \mathrm{mol}$ eq. Trolox $/ \mathrm{g}$ and $7.36 \pm 0.53 \mathrm{mg} \mathrm{GAE} / \mathrm{g}$, respectively, after being subjected to PAR. Conclusively, high Andean microalgae possess adaptation mechanisms that help them to cope with a high radiation flux. The high concentrations of antioxidants and pigments in the strain taken from 4,400 m.a.s.l (IMP-BG288) suggest its greatest cosmetic potential.
\end{abstract}

\section{INTRODUCTION}

The study of the effect of ultraviolet radiation (UVR) on autotrophic organisms of Andean lakes has increased in the last few years. Studies were conducted to evaluate the adaptation mechanisms of these organisms against light stress (Bashevkin et al., 2019; Cartuche et al., 2019; de Oliveira et al., 2016; Rojo et al., 2017; Roleda et al., 2012; Villafañe et al., 2017; Villafañe et al., 2005; Williamson et al., 2019) and to search for novel industrially relevant compounds (Ariede et al., 2017; Joshi et al., 2018; Wang, 2015).

Generally, algae in the areas exposed to radiation possess mechanisms, including photorepair, antioxidant system activation, and biosynthesis of photoprotective compounds

*Corresponding Author
E-mail:Itenorio@imarpe.gob.pe
(Abu-Ghosh et al., 2021; Häder et al., 2007; Holzinger et al., 2018; Ljubic et al., 2021; Rastogi et al., 2020; Singh et al., 2019; Virtanen et al., 2019). These mechanisms are employed to maximize the light capture, limit the damage caused by excessive amounts of solar radiation (Morgan-Kiss et al., 2006), and optimize their photosynthetic performance against UVR (Franklin et al., 2003).

UVR, known to produce reactive oxygen species (ROS), is classified according to wavelengths: UVA (320-400 nm), UVB (280-320 nm), and UVC (200-280 nm). Radiation increases by a combination of factors, such as latitudinal location, ozone, and altitude (Albarracín et al., 2013; Feister and Häder, 2018; Helbling et al., 2001; Michelutti et al., 2015; Ruescas et al., 2016; Villafañe et al., 1999). On evaluating the altitude effect on Lake Titicaca $(3,810$ m.a.s.l.), one of the most important high Andean lakes in Peru, an increase of $4.8 \%$ in the quantity of UVR weighted for every $300 \mathrm{~m}$ altitude was recorded (Andrade et al., 1998). 
The microalgae of the chlorophyte group are better adapted to UVR since they possess highly efficient mechanisms, such as accessory pigments, which protect the cytoplasm and chloroplast and allow individual cells to resist extreme conditions (Chiu et al., 2020; Holzinger and Lütz, 2006). The pigments associated with the algal photosynthetic activity include chlorophylls, $\beta$-carotene, astaxanthin, xanthophylls, and phycobiliproteins. Most carotenoids have certain antioxidant activities due to the presence of conjugated double bonds, which eliminate UVR-induced free radicals (Huang et al., 2018).

Generally, algae have a variety of bioactive compounds, such as pigments, polysaccharides, polyphenols, lipids, and proteins, as well as antioxidant, anti-inflammatory, antipigmentation, antiaging, and anticancer properties. Therefore, they are used as skincare alternatives as they are considered less harmful than synthetic compounds (Morocho-Jácome et al., 2020b; Thiyagarasaiyar et al., 2020). In addition, other secondary metabolites, such as flavonoids, could prevent UVR sunburn in humans with light-sensitive skin and low melanin levels (Morocho-Jácome et al., 2020a).
Currently, some notable cosmetic applications of the extracts of Spirulina sp. and Chlorella sp. include their use as ingredients for sunscreen (Jha et al., 2017), dandruff treatment, and hair growth stimulation (Joshi et al., 2018). Chlorogloeopsis sp. and Nannochloropsis sp. protect keratinous tissue and prevent UVA- and UVB-induced damage, photoaging, wrinkle formation, and sagging skin (Ariede et al., 2017). Isochrysis sp. is applied in sunscreen formulations containing organic and inorganic filters with sun protection factor 15 in order to prevent UVR transmission. Thalassiosira sp., Monodus sp., Chlorococcum sp., and Chaetoceros sp. are applied to prevent hair loss (Zanella et al., 2018). Formulations with oil of Chlorella sp. make the skin and hair softer and more flexible (Brooks and Franklin, 2013). The hydroxy acids in Pediastrum duplex are potential skin moisturizers (Yarkent et al., 2020).

This study aims to collect microalgae from high Andean areas and evaluate their potential as natural ingredients for the cosmetic industry. In this regard, microalgae of the genus Pediastrum were collected from lagoons of altitudes between 3,110 and 4,400 m.a.s.l. Adaptation of the microalgae to

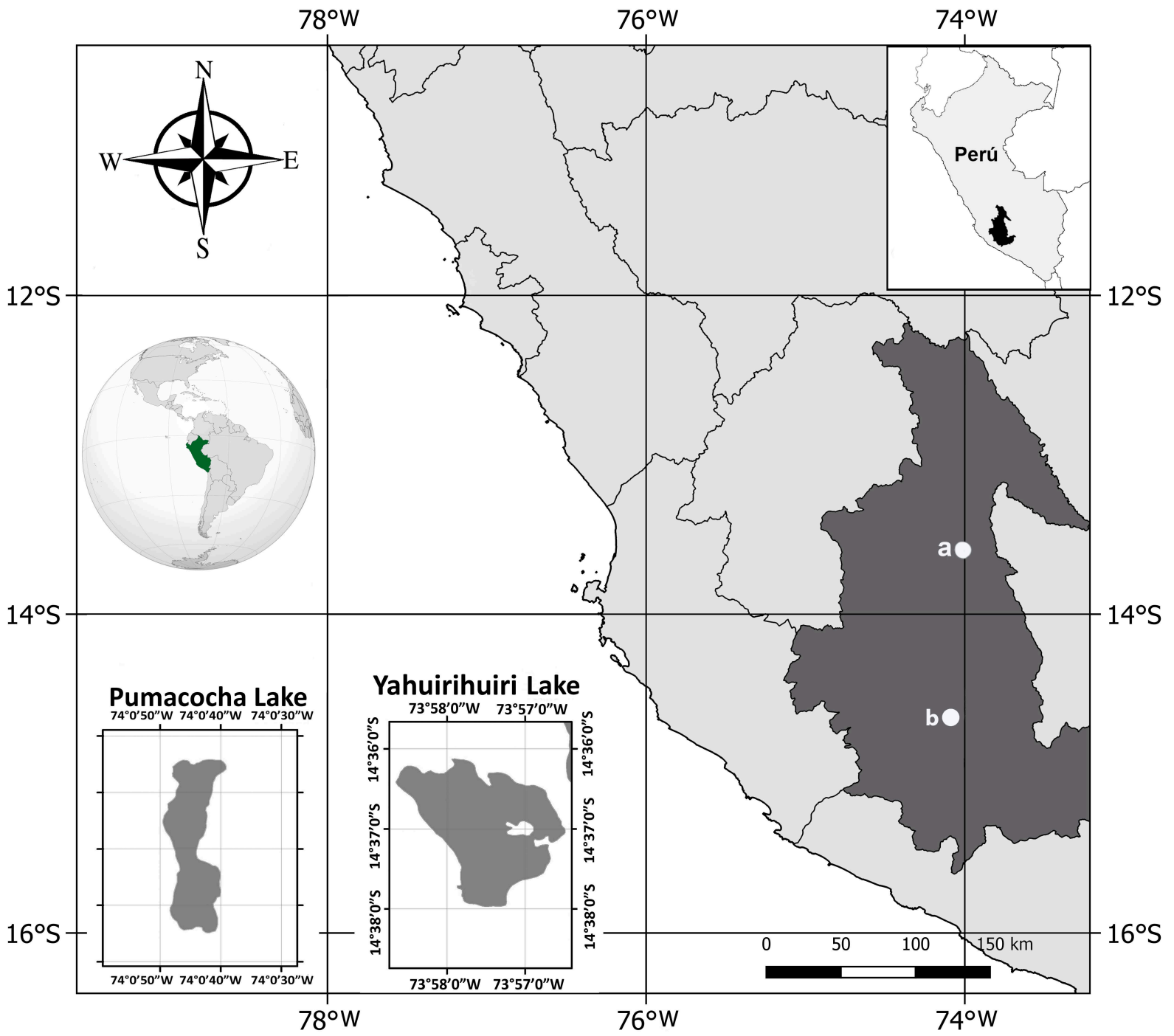

Figure 1. Location of the sampling areas in Ayacucho (Peru). a: Pumacocha Lake. b: Yahuirihuiri Lake. 
photosynthetically active radiation (PAR) and PAR with ultraviolet $\mathrm{A}$ and $\mathrm{B}(\mathrm{PAB})$ was evaluated in the production of photoprotective compounds, such as pigments, antioxidant activity, and total polyphenols.

\section{MATERIALS AND METHODS}

\section{Sampling and isolation of microalgae strains}

In the Andean lagoons of Yahuirihuiri and Pumacocha, located in the Department of Ayacucho, Peru (Fig. 1), microalgae samples were collected with a $20 \mu \mathrm{m}$ phytoplankton network. The samples were placed in $50 \mathrm{ml}$ Falcon ${ }^{\circledR}$ tubes, stored in thermal boxes with a gel pack, and then transferred to the Laboratory of the Germplasm Bank of Aquatic Organisms (BGOA) of the Marine Institute of Peru. Monoclonal strains of microalgae of the genus Pediastrum were obtained through the cell isolation methodology described by Andersen and Kawachi (2005) and using inverted phase-contrast microscopy (Nikon, Eclipse TS100, Japan). For the cultivation of Pediastrum sp, a Wright's cryptophyte (WC) culture medium (Andersen et al., 2005; Guillard and Lorenzen, 1972) was used in a growth chamber (Binder KBW400, Germany) under the following conditions: $18^{\circ} \mathrm{C} \pm 1{ }^{\circ} \mathrm{C}, 80 \mu \mathrm{mol} . \mathrm{s}^{-1} \cdot \mathrm{m}^{-2}$, and a 2:12 hours light:dark photoperiod. These monoclonal strains were classified based on their morphology (Lenarczyk and Saługa, 2018; Zamaloa and Tell, 2005) and assigned codes (Table 1) to integrate them into the BGOA collection.

\section{Experimental design}

Strains of Pediastrum were cultivated inside a culture chamber in 21 rectangular parallelepiped photobioreactors $(26 \times$ $15.1 \times 5.1 \mathrm{~cm})$ with the WC culture medium. The average initial cell density of the cultures was $9.35 \times 10^{5}$ cells $/ \mathrm{ml}$.

For a period of 8 days, two radiation levels were applied to the cultures. All the following cultures were carried out in triplicate: a) PAR $\left(80 \mu \mathrm{mol} . \mathrm{S}^{-1} \mathrm{~m}^{-2}\right)$ with a $12: 12$ hours (light:dark) photoperiod and b) PAB with a 12:12 hours (light:dark) photoperiod; 3 hours after starting the PAR luminous phase $\left(80 \mu \mathrm{mol} . \mathrm{S}^{-1} \mathrm{~m}^{-2}\right)$, UV radiation (UVA + UVB, $4 \mathrm{~mW} / \mathrm{cm}^{2}$ ) was activated for 3 hours.

PAR was recorded using a quantometer (Liquor Quantimeter), whereas UVR was recorded using a radiometer (UVP UVX, USA). All treatments were carried out at $18^{\circ} \mathrm{C} \pm 1{ }^{\circ} \mathrm{C}$ and at constant aeration for 8 days. Samples $(1 \mathrm{ml})$ were taken from each experimental unit every 24 hours and were fixed with Lugol for cell quantification.

Finally, cultures were harvested on the eighth day and the biomass was concentrated by centrifugation $(3,500 \mathrm{rpm}$ for 10 minutes at $5^{\circ} \mathrm{C}$ ) in a refrigerated centrifuge (Hettich, Germany).
The wet biomass was dried in a lyophilizer (Labconco, EEUU) and stored at $8^{\circ} \mathrm{C}$ in a dark and cold environment.

\section{Specific growth rate}

The cell density of the cultures was evaluated through the cell counting method with a Neubauer camera on a compound microscope (Nikon, Japan). The specific growth rate $(\mu)$ was determined using the following formula:

$$
\mu=\left(\ln x_{2}-\ln x_{1}\right) /\left(t_{2}-t_{1}\right),
$$

Where $t_{2}$ is the final time, $t_{1}$ is the initial time, $x_{1}$ is the initial cell density, and $x_{2}$ is the final cell density.

\section{Determination of pigments}

Pigments were extracted from $50 \mathrm{mg}$ of the lyophilized microalgae with $6 \mathrm{ml}$ of $100 \%$ acetone as per the protocol of Pasquet et al. (2011). Samples were filtered using a $4.5 \mu \mathrm{m}$ polytetrafluoroethylene syringe filter, and $20 \mu \mathrm{l}$ of the filtrate was used to carry out high-performance liquid chromatography (Hitachi, Tokyo). The Merck LiChrospher ${ }^{\circledR} \mathrm{C} 18250 \times 4.6 \mathrm{~mm} \times 5 \mu \mathrm{m}$ analytical column was used. The mobile phases were $\mathrm{A}=100 \%$ methanol, $\mathrm{B}=$ methanol:0.5 $\mathrm{N}$ ammonium acetate $(80: 20)$, and $\mathrm{C}=$ tetrahydrofuran. The ramp was $0.0 \mathrm{~min}(0 \% \mathrm{~A}, 100 \% \mathrm{~B}$, and $0 \% \mathrm{C})$, 5.0 minutes $(98 \% \mathrm{~A}, 0 \% \mathrm{~B}$, and $2 \% \mathrm{C}), 17.2$ minutes $(80 \% \mathrm{~A}, 0 \% \mathrm{~B}$, and $20 \% \mathrm{C}$ ), 25.0 minutes ( $80 \% \mathrm{~A}, 0 \% \mathrm{~B}$, and $20 \% \mathrm{C}), 26.0$ minutes $(98 \% \mathrm{~A}, 0 \% \mathrm{~B}$, and $2 \% \mathrm{C})$, and 34.0 minutes $(0 \% \mathrm{~A}, 100 \% \mathrm{~B}$, and $0 \% \mathrm{C}$ ). The column temperature was maintained at $25^{\circ} \mathrm{C}$. Spectra at the 210 and $690 \mathrm{~nm}$ wavelengths were recorded. The analytical standards (Sigma-Aldrich) of lutein, chlorophyll a, chlorophyll b, and $\beta$-carotene were used as references to quantify the pigments.

\section{Determination of total polyphenols}

The polyphenols were extracted from $50 \mathrm{mg}$ of the lyophilized biomass using $6 \mathrm{ml}$ of $100 \%$ acetone and subsequently with $6 \mathrm{ml}$ of ultrapure water. Total polyphenols in the extracts were analyzed following the methods described by Singleton and Rossi (1965). The calibration curve was prepared using gallic acid at a concentration range of $100-500 \mu \mathrm{g} / \mathrm{ml}$. The absorbance was measured at $760 \mathrm{~nm}$ using a spectrophotometer (Varian, Australia). The values obtained in triplicate were expressed in $\mathrm{mg}$ GAE/g. The total polyphenol content was considered as the sum of the aqueous and acetone fractions.

\section{Determination of antioxidant activity}

Overall, $50 \mathrm{mg}$ of the lyophilized biomass was used to determine the antioxidant activity and exhaustive extraction was carried out using three solvents: hexane, acetone, and water. The hexane and acetone extracts were evaporated by injecting

Table 1. Pediastrum strain from high Andean lakes from the Department of Ayacucho, geographic coordination, and BGOA code.

\begin{tabular}{ccccc}
\hline Strain & Code & Lake & $\begin{array}{c}\text { Altitude } \\
\text { (m.a.s.l.) }\end{array}$ & Latitude, longitude \\
\hline Pediastrum sp. & IMP-BG288 & Yahuirihuiri Lake & 4,400 & $14^{\circ} 37.85^{\prime} \mathrm{S}, 73^{\circ} 57.17^{\prime} \mathrm{W}$ \\
Pediastrum sp. & IMP-BG255 & Pumacocha Lake & 3,311 & $13^{\circ} 35.49^{\prime} \mathrm{S}, 74^{\circ} 00.76^{\prime} \mathrm{W}$ \\
\hline
\end{tabular}




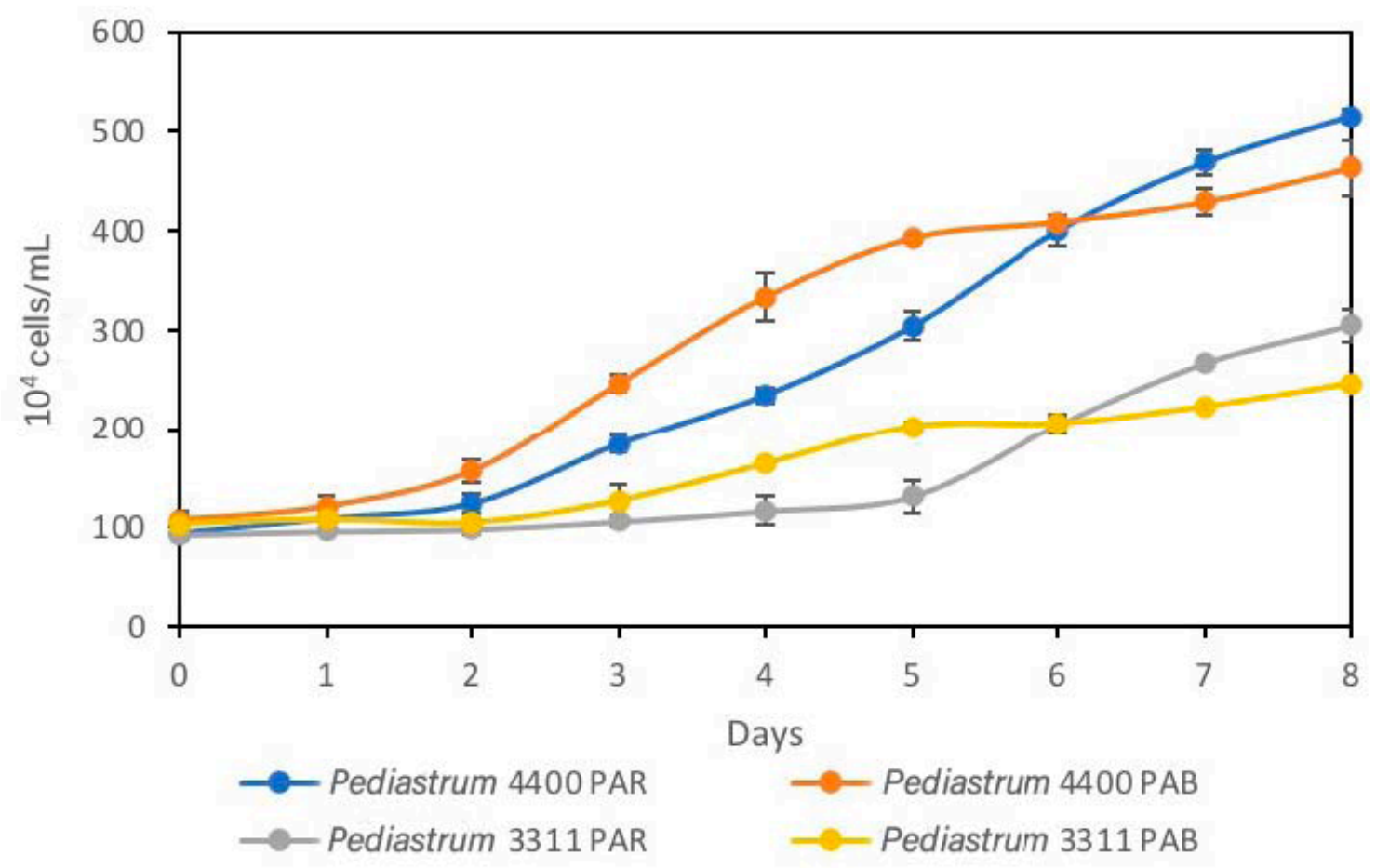

Figure 2. Effect of PAR and PAB radiations on growth of the strains IMP-BG288 (4,400 m.a.s.l) and IMP-BG255 (3,111 m.a.s.l).

nitrogen gas and resuspended in $2 \mathrm{ml}$ of absolute ethanol. This was carried out in triplicate to quantify the antioxidant activity. The antioxidant activity of the extracts was determined using the (2,2'-azino-bis(3-ethylbenzothiazoline-6-sulfonic acid)) + (2,2'-azinobis-(3-ethylbenzothiazoline-6-sulfonic acid)) radical cation method, as described by Re et al. (1999). Absorbance was measured at $714 \mathrm{~nm}$ using a spectrophotometer (Varian, Australia). The values obtained were expressed in $\mu \mathrm{mol}$ eq. Trolox/g. The total antioxidant activity was considered as the sum of the hexane, acetone, and aqueous fractions.

\section{Statistical analysis}

Data obtained from the growth, antioxidant activity, pigments, and polyphenol assays were analyzed using the analysis of variance at a significance level of $\alpha=0.05$. Means were compared using Tukey's post hoc test. All statistical analyses were carried out using the MINITAB 16 program.

\section{RESULTS AND DISCUSSION}

\section{Growth of Pediastrum sp. after PAR and PAB radiation}

The Pediastrum cultures subjected to $\mathrm{PAB}$ radiation showed a short latency phase: 1 day for IMP-BG288 and 2 days for IMP-BG255. Concurrently, the same strains subjected to PAR radiation showed latency phases of 2 and 4 days, respectively (Fig. 2). This indicates that the strains from these high Andean areas are genetically conditioned to modulate UVR stress. In this case, growth stimulation was observed. Also, UVR photostress reduced the latency phase in Chlorella vulgaris (NIOT5 India) (Balan and Suraishkumar, 2014).
Between the third and fourth days, the cultures of Pediastrum sp. taken from 4,400 and 3,311 m.a.s.1. and exposed to $\mathrm{PAB}$ radiation (Table 2) showed the highest specific growth rate. This is due to the adaptation ability of this strain to high radiation (Andrade et al., 1998). The differences in the growth rates of Pediastrum sp. strains could be as a result of an adaptive photoprotection response that is associated with specific species (Janknegt et al., 2009; Wong et al., 2007). In C. vulgaris, the specific growth rate $(\mu)$ was 0.39 when it was exposed to UVA+B radiation. This was higher than the control, in which UVB radiation generated an increase in the growth rate during the early growth phase. This is as a result of changes in the photosystem stoichiometry and the size of the antenna pigments (Balan and Suraishkumar, 2014).

On the sixth day, the cultures of Pediastrum sp. exposed to PAR radiation were found in the exponential phase. However, the cultures exposed to PAB radiation showed a delay in their growth, entering a short period of stationary phase between days 5 and 6 (Fig. 2). It should be mentioned that similar densities were observed on day 6 of the cultivation in the strains exposed to PAR and PAB radiation. This short period of stationary phase was because UVR exposure induces oxidative stress in microalgae

Table 2. Effect of PAR and PAB radiations on specific growth rate $(\mu)$ in the exponential phase (third and fourth days) of Pediastrum sp.

\begin{tabular}{ccc}
\hline Treatments & & $\mu$ \\
\hline \multirow{2}{*}{ IMP-BG288 (4,400 m.a.s.1.) } & PAR & $0.19 \pm 0.10^{\mathrm{a}}$ \\
& PAB & $0.30 \pm 0.04^{\mathrm{b}}$ \\
IMP-BG255 (3,311 m.a.s.1.) & PAR & $0.09 \pm 0.09^{\mathrm{c}}$ \\
& PAB & $0.26 \pm 0.15^{\mathrm{b}}$ \\
\hline
\end{tabular}

Different letters mean statistically significant differences $(\mathrm{p}<0.05$, Tukey's test). 
(Paliwal et al., 2017; Tian and Yu, 2009). This shows that the repair mechanisms for the genes regulating photosynthesis and metabolic stress are rapid, which activate the antioxidant systems and DNA repair (Brosché and Strid, 2003; Buma et al., 2003; Helbling et al., 2001; Portwich and Garcia-Pichel, 2000; Sijil et al., 2020). Nevertheless, between days 7 and 8 , the cultures of both strains showed significant increases in their cell density. Similar specific growth rates were observed in the cultures of IMP-BG288 $(0.08$ and 0.09) and IMP-BG255 (0.10 and 0.13) strains exposed to PAB and PAR, respectively.

The adaptive response of Pediastrum sp. strains derived from lagoons at different heights above sea level to UVR was expressed in the growth stages. Xiong et al. (1996) evaluated the growth of microalgae from several regions and demonstrated that the microalgae from high altitude areas adapt to radiation. This was because this factor induces different genes that encode for proteins involved in the biosynthesis of photoprotective pigments, such as those involved in the regulation of photosynthesis and metabolic stress, as well as those involved in the stimulation of enzyme systems, antioxidants, and DNA repair (Barrado-Moreno et al., 2017; Brosché and Strid, 2003; Buma et al., 2003; Helbling et al., 2001; Portwich and Garcia-Pichel, 2000).

\section{Pigments}

Chlorophyll $\mathrm{a}$ and $\mathrm{b}$ in both Pediastrum strains decreased after PAB exposure $(p<0.05)$ (Fig. 3). Chlorella vulgaris, Chlorococcum infusionum (Schrank) Meneghini, and Chlorogonium elongatum (Dang.) showed similar results in terms of chlorophyll concentrations when exposure to UVB was increased (Agrawal, 1992; Ganapathy et al., 2017).

In addition, lutein was the most abundant pigment ( $>5 \mathrm{mg} / \mathrm{g}$ ) in the two Pediastrum strains that were subjected to $\mathrm{PAR}$ and $\mathrm{PAB}$ radiation. The pigment content decreased in cultures exposed to PAB radiation $(p<0.05)$. The concentration of lutein in the cultures of the algae Aglaothamnion uruguayense exposed to PAB and PAR was observed to be higher in the cultures after PAB radiation (Ouriques et al., 2017).

The $\beta$-carotene concentrations of the two Pediastrum strains exposed to PAR and PAB showed no significant differences $(p>0.05)$. However, there were no apparent changes $(p>0.05)$ in Dunaliella salina when exposed to UVR. This demonstrated that carotenoids were more associated with antioxidants than photosynthetic pigments (Tian and Yu, 2009). Generally, the accumulation of pigments at high radiation and light intensity occurs in a short period of time in some algae regulated by photomorphogenic photoreceptors (Wang et al., 2007).

In addition, the percentages of lutein and chlorophylls when exposed to PAB radiation decreased by $20 \%-24 \%$ and $45 \%-67 \%$, respectively, for both strains. The concentrations of chlorophyll a and carotenoids significantly decreased in the cultures containing Phormidium tenuous and Nostoc muscorum by over $70 \%$ and $80 \%$, respectively (Agrawal and Chaudhary, 1996; Bhandari and Sharma, 2011).

In summary, our results indicate that when microalgae Pediastrum cultures were subjected to $\mathrm{PAB}$ radiation, the concentrations of lutein, chlorophyll a, and chlorophyll b were significantly $(p<0.05)$ low on the eighth day compared with those exposed to PAR.

In addition, algae pigments have antiaging, antioxidant, and neuroprotective properties, which make them suitable for use in cosmetics industries (Berthon et al., 2017; Yarkent et al., 2020). Also, pigments, such as chlorophyll a, chlorophyll b, $\beta$-carotene, and lutein, can be used in the cosmetic industry as antioxidants, anti-inflammatories, antiwrinkles products, and moisturizers, as well as in collagen synthesis, for skin elasticity, and to prevent premature aging (Joshi et al., 2018; Wang, 2015).

According to our results, the strain IMP-BG288 exposed to $\mathrm{PAR}$ radiation can possibly have great cosmetic potential. This is

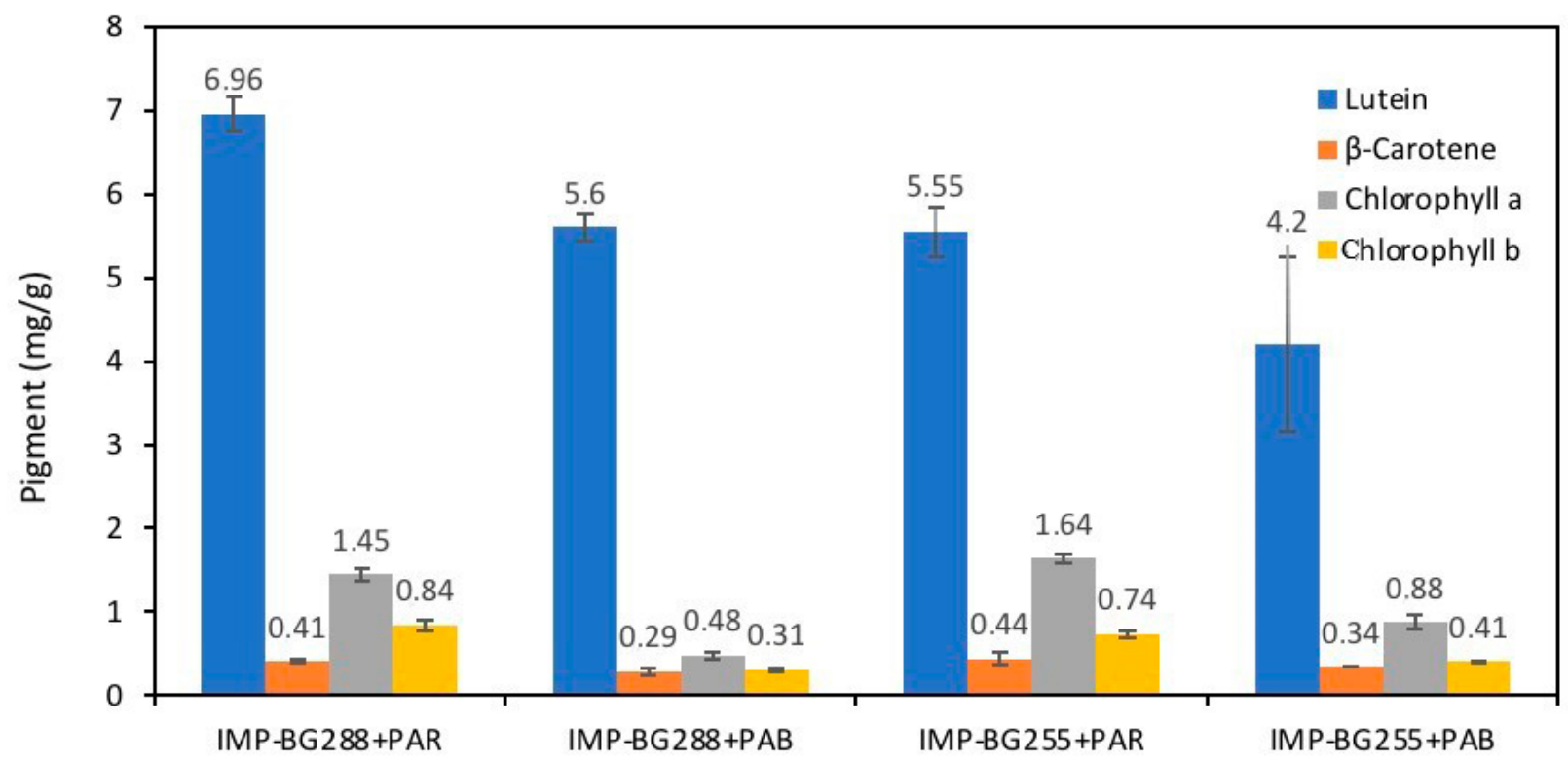

Figure 3. Concentration of lutein, $\beta$-carotene, chlorophyll a, and chlorophyll b (mg/g) in cultures of IMP-BG288 and IMP-BG255 strains of Pediastrum sp. exposed to PAR and PAB radiation. 


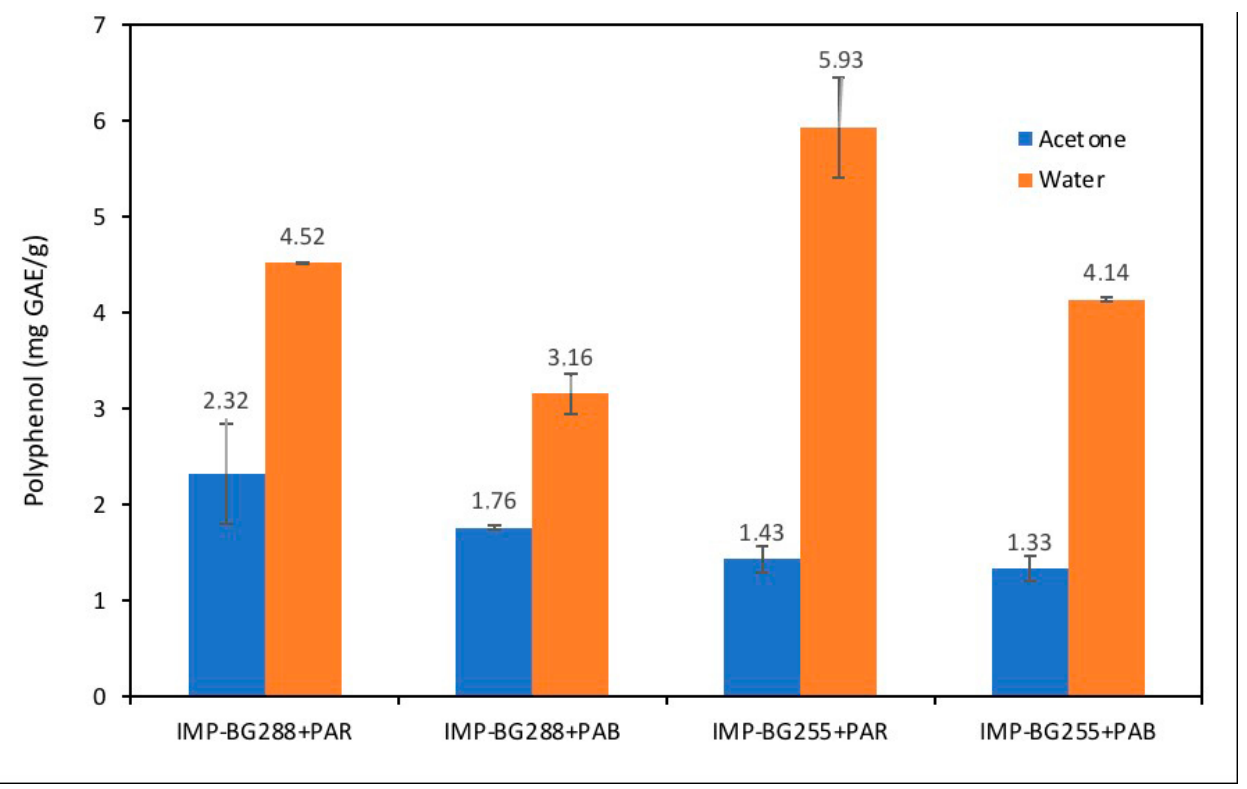

Figure 4. Phenolic contents (mg GAE/g) of different fractions of Pediastrum sp.

because lutein is an intracellular algae product that has a protective effect on the skin when combined with other antioxidants and immunoprotective substances (Wang, 2015). It can also be applied as a colorant in the cosmetic industry (Sathasivam et al., 2019).

\section{Polyphenols}

Polyphenols show antioxidant properties and antiradical, antiallergic, anti-inflammatory, and UV protective properties which can react directly with ROS, forming less reactive products (AbuGhosh et al., 2021; Berthon et al., 2017; Moskaug et al., 2005).

The aqueous fraction of both strains (IMP-BG288 and IMP-BG255) of Pediastrum recorded values between 3.0 and $6.0 \mathrm{mg} \mathrm{GAE} / \mathrm{g}$, respectively. These values were higher than those reported by Li et al. (2007) for the aqueous fraction of the Chlorella group (0.97 to $2.67 \mathrm{mg} \mathrm{GAE} / \mathrm{g}$ ) and lower than that of Nostoc ellipsosporum CCAP 1453/17 (10.68 mg GAE/g). It should be noted that the polyphenol concentrations of cultures of both strains exposed to PAB radiation significantly decreased ( $p<$ 0.05) when compared with those exposed to PAR (Fig. 4).

However, the polyphenols extracted using acetone did not show significant differences $(p>0.05)$ in the two Pediastrum strains subjected to PAR and PAB radiation.

Duval et al. (2000) observed similar results when UVA radiation was emitted in a species of Chlamydomonas nivalis collected from 3,100 m.a.s.l. These polyphenol extracts (ethanol) did not show significant differences with UVA exposure for up to 15 days.

In relation to total polyphenols, both strains (IMP-BG288 and IMP-BG255) of Pediastrum had values between 4.90 and 7.40 mg GAE/g. Li et al. (2007) evaluated the total polyphenols in four different strains of $N$. ellipsosporum, reporting values between 7.2 and $60.4 \mathrm{mg} \mathrm{GAE} / \mathrm{g}$. In three strains of Chlorella pyrenoidosa, values between 10.46 and $17.24 \mathrm{mg} \mathrm{GAE} / \mathrm{g}$ were reported. Also, the three strains of $C$. vulgaris had values between 8.6 and $15.0 \mathrm{mg} \mathrm{GAE} / \mathrm{g}$.

Polyphenols are necessary for the cosmetic industry due to the essential biological properties they possess. Hence, in this study, both Pediastrum strains have similar cosmetic potential based on their total polyphenols content.

\section{Antioxidant activity}

In this study, for Pediastrum sp., the UVR dose of 4 $\mathrm{mW} . \mathrm{cm}^{-2}$ acts as an inducer of the biosynthesis of photoprotective and antioxidant compounds. This allows the species to achieve a homeostatic balance against stress generated by exposure to UVR (Rastogi et al., 2020). However, the response will be different, depending on the place of origin and species. Wong et al. (2007) observed that the sensitivity of microalgae to UVB stress varied according to the species and geographical location. The strain IMP-BG288 from the lagoon at 4,400 m.a.s.1. showed significantly higher antioxidant activity $(p<0.05)$ than that of the strain IMPBG255 from 3,100 m.a.s.l. This result confirms that microalgae species that inhabit lagoons exposed to high UVR have better protection mechanisms, which is reflected in the outstanding antioxidant activity of the strain IMP-BG288 (Fig. 5).

The total antioxidant activity in the cultures of the strains of Pediastrum sp. when exposed to PAB radiation did not show any significant differences $(p>0.05)$ compared with when exposed to PAR. The IMP-BG288 Pediastrum strain recorded high values in the acetone fraction $(>149.0 \mu \mathrm{mol}$ eq. Trolox $/ \mathrm{g})$ when exposed to both PAR and PAB radiations compared to those of the water and hexane fraction. In addition, the strain IMP-BG255 showed higher values in the aqueous fraction ( $>49.0 \mu \mathrm{mol}$ eq. Trolox $/ \mathrm{g}$ ) when exposed to both PAR and PAB radiations (Fig. 5). This is because the antioxidant compounds of microalgae can vary significantly in polarity, with marked differences even within the same families and species (Li et al., 2007).

The total antioxidant activity of the strain IMP-BG288 for both treatments had values greater than 210.0 umol eq. Trolox/g with regard to the records of microalgae species, such as Botryococcus braunii (53.90 umol eq. Trolox/g), Chlorella sp. (59.57 umol eq. Trolox/g), Tetraselmis suecica (56.46 umol eq. Trolox/g), Neochloris oleoabundans (64.30 umol eq. Trolox/g), 


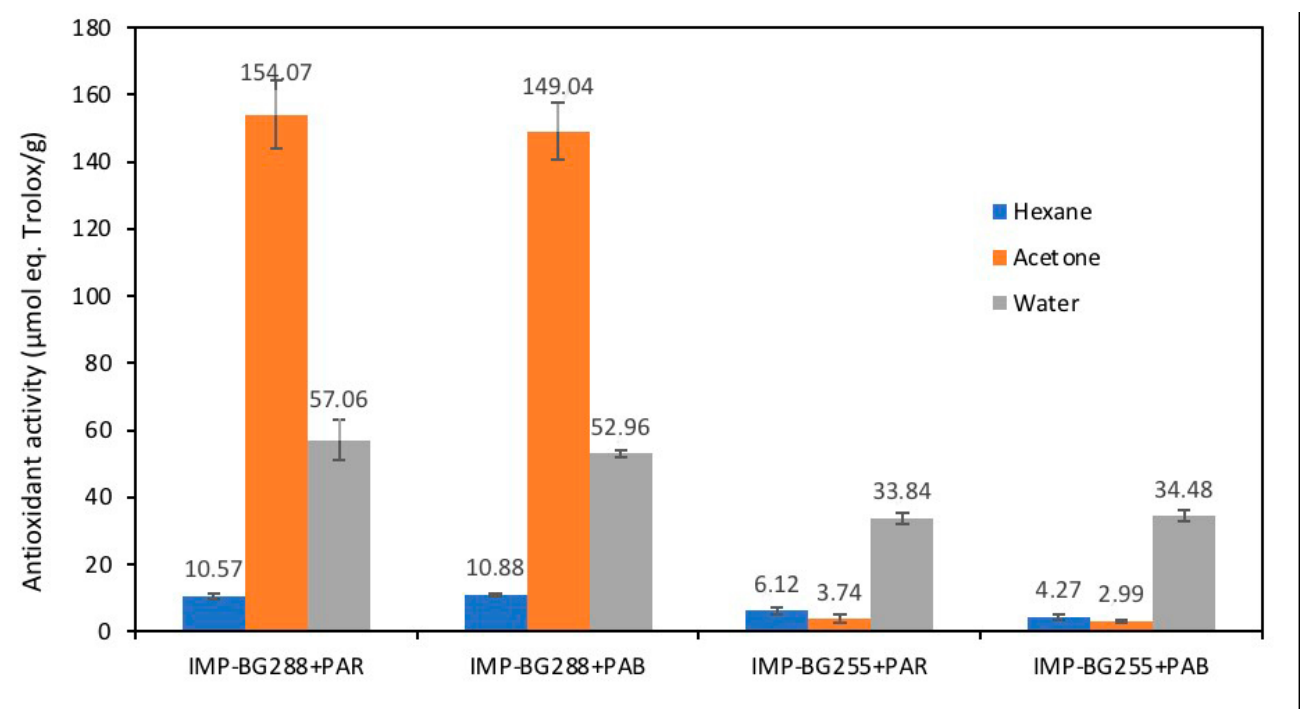

Figure 5. Antioxidant activity ( $\mu \mathrm{mol}$ eq. Trolox/g) of different fractions in Pediastrum sp.

Anabaena cylindrica (54.81 umol eq. Trolox/g), C. vulgaris $(58.24$ umol eq. Trolox/g), Fischerella ambigua (74.34 umol eq. Trolox/g), and Nostoc piscinale (65.84 umol eq. Trolox/g) (Goiris et al., 2012).

These results imply that habitat is vital for the synthesis of antioxidants as the antioxidant content was higher in the strains from 4,400 m.a.s.l. than those from 3,100 m.a.s.l. As a result of the increase in the photoprotection and antioxidant capacity of the skin, these antioxidants could be extracted from the algal biomass and used to develop cosmetic products (Ariede et al., 2017; Mourelle et al., 2017; Puchkova et al., 2020; Thiyagarasaiyar et al., 2020; Wang, 2015). In addition, investigations on Pediastrum boryanum have shown high potential in natural antioxidants, which has other areas of application (Corrêa da Silva et al., 2020; Lee et al., 2009). It is important to note that plants from environments exposed to UVR and only PAR do not activate their metabolic routes (Holzinger and Lütz, 2006). However, this induces possible side effects, such as low concentrations of the antioxidants, which enable them to have defensive mechanisms against pathogens.

\section{CONCLUSION}

Microalgae from high Andean lagoons have adaptation mechanisms, which enable them to cope with the high radiation flux. The Pediastrum sp. strain from the lagoon at 4,400 m.a.s.1. showed greater growth after PAB radiation treatment compared with PAR. Also, the strain from the lagoon at 3,310 m.a.s.l. showed prolonged growth in the adaptation phase.

Pediastrum strains from the high Andean lagoons are potential natural ingredients for the cosmetic industry. The strain from 4,400 m.a.s.1. (IMP-BG288) demonstrated the greatest potential due to its high concentrations of antioxidants and pigments. However, the use of UV radiation to achieve an increase in the concentrations of these metabolites is not recommended. Continuous investigation of the strain from 4,400 m.a.s.1. through cosmetic efficacy tests is suggested as this will help in evaluating its application as a cosmetic ingredient.

\section{ACKNOWLEDGMENTS}

The authors are grateful to the "Budget National Program N094 (PpR094)": "Management and Development of Aquaculture"-PRODUCE, Peru, through the project "Technological Development in Aquaculture".

\section{CONFLICT OF INTERESTS}

The authors report no financial or any other conflicts of interest in this work.

\section{FUNDING}

The funding of this research was supported by To the Programa Nacional de Ciencia y Tecnología - FONDECYT that financially supported this research by the project "Search, characterization and cultivation of microalgae of Andean highlands of Peru that are potentially useful in the cosmetic industry", Agreement N ${ }^{\circ}$ 201-2015-FONDECYT.

\section{ETHICAL APPROVALS}

This study does not involve experiments on animals or human subjects.

\section{DATA AVAILABILITY}

All data generated and analyzed are included within this research article.

\section{PUBLISHER'S NOTE}

This journal remains neutral with regard to jurisdictional claims in published institutional affiliation.

\section{REFERENCES}

Abu-Ghosh S, Dubinsky Z, Verdelho V, Iluz D. Unconventional highvalue products from microalgae: A review. Bioresour Technol, 2021; 329:124895.

Agrawal S. Effects of supplemental UV-B radiation on photosynthetic pigment, protein and glutathione contents in green algae. Environ Exp Bot, 1992; 32(2):137-43.

Agrawal SB, Chaudhary BR. Chrysophyte cytology: compilation and evaluation. In: Chaudhary BR, Agrawal SB (ed.). Cytology, genetics 
and molecular biology of algae, SPB Academic Publishing, Amsterdam, The Netherlands, pp 173-91, 1996.

Albarracín VH, Gärtner W, Farias ME. UV Resistance and photoreactivation of extremophiles from high-altitude Andean lakes. J Photochem Photobiol B: Biol, 2013; 4:1-4.

Andersen RA, Berges J, Harrison P, Watanabe M. Appendix, a-recipes for freswater and seawater media. In: Andersen RA (ed.). Algal culturing techniques, Elsevier, Amsterdam, Netherlands, pp 429-538, 2005.

Andersen RA, Kawachi M. Tradiotinal microalgae isolation techniques. In: Andersen RA (ed.). Algal culturing techniques, Elsevier, Amsterdam, Netherlands, pp 83-100, 2005.

Andrade M, Forno R, Palenque E, Zaratti F. Estudio preliminar del efecto de altura sobre la radiación solar ultravioleta B. Rev Bol Fis, 1998; 4:14.

Ariede MB, Candido TM, Jacome ALM, Velasco MVR, de Carvalho JCM, Baby AR. Cosmetic attributes of algae-a review. Algal Res, $2017 ; 25: 483-7$.

Balan R, Suraishkumar G. Simultaneous increases in specific growth rate and specific lipid content of Chlorella vulgaris through UVinduced reactive species. Biotechnol Progr, 2014; 30(2):291-9.

Barrado-Moreno MM, Beltrán-Heredia J, Martín-Gallardo J. Degradation of microalgae from freshwater by UV radiation. J Ind Eng Chem, 2017; 48:1-4.

Bashevkin SM, Christy JH, Morgan SG. Photoprotective benefits of pigmentation in the transparent plankton community: a comparative species experimental test. Ecology, 2019; 100(5):e02680.

Berthon JY, Nachat-Kappes R, Bey M, Cadoret JP, Renimel I, Filaire E. Marine algae as attractive source to skin care. Free Radical Res, 2017; 51(6):555-67.

Bhandari RR, Sharma PK. Photosynthetic and biochemical characterization of pigments and UV-absorbing compounds in Phormidium tenue due to UV-B radiation. J Appl Phycol, 2011; 23(2):283-92.

Brooks G, Franklin S, Google Patents. Cosmetic compositions comprising microalgal components. 8,557,249,. 15 oct. 2013.

Brosché M, Strid $\AA$. Molecular events following perception of ultraviolet-B radiation by plants. Physiol Plant, 2003; 117(1):1-10.

Buma AG, Boelen P, Jeffrey WH. UVR-induced DNA damage in aquatic organisms. In: Helbling EW, Zagarese HE (eds.). UV effects in aquatic organisms and ecosystems. The Royal Society of Chemistry, Cambridge, UK, pp 291-327, 2003.

Cartuche A, Guan Z, Ibelings BW, Venail P. Phytoplankton diversity relates negatively with productivity in tropical high-altitude lakes from Southern Ecuador. Sustainability, 2019; 11(19):5235.

Chiu C, Chiu P, Yong TC, Tsai H, Soong K, Hsiang H, Chen $\mathrm{CN}$. Mechanisms protect airborne green microalgae during long distance dispersal. Sci Rep, 2020; 10:13984.

Corrêa da Silva MG, Pires Ferreira S, Dora CL, Hort MA, Giroldo D, Prates DF, Radmann EM, Bemvenuti RH, Costa JAV, BadialeFurlong E. Phenolic compounds and antioxidant capacity of Pediastrum boryanum (Chlorococcales) biomass. Int J Env Health Res, 2020:1-13.

de Oliveira EM, Schmidt ÉC, Pereira DT, Bouzon ZL, Ouriques LC. Effects of UV-B radiation on germlings of the red macroalga Nemalion helminthoides (Rhodophyta). J Microsc Ultrastruct, 2016; 4(2):85-94.

Duval B, Shetty K, Thomas WH. Phenolic compounds and antioxidant properties in the snow alga Chlamydomonas nivalis after exposure to UV light. J Appl Phycol, 2000; 11(6):559-66.

Feister U, Häder DP. Solar UV radiation and penetration into water. In: Aquatic ecosystems in a changing climate, CRC Press, London, UK, pp 12-31, 2018

Franklin LA, Osmond CB, Larkum AW. Photoinhibition, UV-B and algal photosynthesis. In: Larkum AWD, Douglas SE, Raven JA (eds.). Photosynthesis in algae, Springer, Dordrecht, Netherlands, pp 351-84, 2003.

Ganapathy K, Chidambaram K, Janarthanan R, Ramasamy R. Effect of UV-B radiation on growth, photosynthetic activity and metabolic activities of Chlorella vulgaris. Res Rev J Microbiol Biotechnol, 2017; $6(2): 53-60$.
Goiris K, Muylaert K, Fraeye I, Foubert I, De Brabanter J, De Cooman L. Antioxidant potential of microalgae in relation to their phenolic and carotenoid content. J Appl Phycol, 2012; 24(6):1477-86.

Guillard RR, Lorenzen CJ. Yellow-green algae with chlorophyllide C 1, 2. J Phycol, 1972; 8(1):10-4.

Häder DP, Kumar H, Smith R, Worrest R. Effects of solar UV radiation on aquatic ecosystems and interactions with climate change. Photochem Photobiol Sci, 2007; 6(3):267-85.

Helbling EW, Villafañe V, Buma A, Andrade M, Zaratti F. DNA damage and photosynthetic inhibition induced by solar ultraviolet radiation in tropical phytoplankton (Lake Titicaca, Bolivia). Eur J Phycol, 2001; 36(2):157-66.

Holzinger A, Albert A, Aigner S, Uhl J, Schmitt-Kopplin P, Trumhová K, Pichrtová M. Arctic, Antarctic, and temperate green algae Zygnema spp. under UV-B stress: vegetative cells perform better than preakinetes. Protoplasma, 2018; 255(4):1239-52.

Holzinger A, Lütz C. Algae and UV irradiation: effects on ultrastructure and related metabolic functions. Micron, 2006; 37(3):190-207.

Huang JJ, Lin S, Xu W, Cheung PCK. Enhancement of the production of bioactive microalgal metabolites by ultraviolet radiation (UVA 365 nm). J Agric Food Chem, 2018; 66(39):10215-24.

Janknegt PJ, De Graaff CM, Van de Poll WH, Visser RJ, Rijstenbil JW, Buma AG. Short-term antioxidative responses of 15 microalgae exposed to excessive irradiance including ultraviolet radiation Eur J Phycol, 2009; 44(4):525-39.

Jha D, Jain V, Sharma B, Kant A, Garlapati VK. Microalgaebased pharmaceuticals and nutraceuticals: an emerging field with immense market potential. Chem Bio Eng Reviews, 2017; 4(4):257-72.

Joshi S, Kumari R, Upasani VN. Applications of algae in cosmetics: an overview. Int J Innov Res Sci Eng Technol, 2018; 7(2):1269.

Lee SH, Kim AD, Kang MC, Lee JB, Jeon YJ. Potential antioxidant activities of enzymatic digests from fresh water microalgae, Pediastrum duplex and Dactylococcopsis fascicularis. Algae, 2009; 24(3):169-77.

Lenarczyk J, Saługa M. Evolutionary relationships between the varieties of green algae Pediastrum boryanum and $P$. duplex sl (Chlorophyceae, Hydrodictyaceae). Fottea, 2018; 18(2):170-88.

Li HB, Cheng KW, Wong CC, Fan KW, Chen F, Jiang Y, Evaluation of antioxidant capacity and total phenolic content of different fractions of selected microalgae. Food Chem, 2007; 102(3):771-6.

Ljubic A, Thulesen ET, Jacobsen C, Jakobsen J. UVB exposure stimulates production of vitamin D3 in selected microalgae. Algal Res, 2021; 59:102472

Michelutti N, Cooke CA, Hobbs WO, Smol JP. Climate-driven changes in lakes from the Peruvian Andes. J Paleolimnol, 2015; 54(1):153-60.

Morgan-Kiss RM, Priscu JC, Pocock T, Gudynaite-Savitch L, Huner NP. Adaptation and acclimation of photosynthetic microorganisms to permanently cold environments. Microbiol Mol Biol Rev, 2006; 70(1):222-52.

Morocho-Jácome AL, de Almeida Cezare-Gomes E, de Carvalho JCM, Sauce R, Rosado C, Velasco MVR, Baby AR. UV-screening from microalgae. In: Jacob-Lopes E, Manzoni Maroneze M, Queiroz MI, Queiroz Zepka L, (eds.). Handbook of microalgae-based processes and products, Academic Press, Cambridge, MA, pp 647-57, 2020a.

Morocho-Jácome AL, Ruscinc N, Martinez RM, de Carvalho JCM, de Almeida TS, Rosado C, Costa JG, Velasco MVR, Baby AR. (Bio) Technological aspects of microalgae pigments for cosmetics. Appl Microbiol Biotechnol, 2020b; 104:1-10.

Moskaug JO, Carlsen H, Myhrstad MC, Blomhoff R. Polyphenols and glutathione synthesis regulation. Am J Clin Nutr, 2005; 81(1):277S-83S.

Mourelle ML, Gómez CP, Legido JL. The potential use of marine microalgae and cyanobacteria in cosmetics and thalassotherapy. Cosmetics, 2017; 4(4):46.

Ouriques LC, Pereira DT, Simioni C, Ramlov F, Maraschin M, Bouzon ZL, Schmidt ÉC. Physiological, morphological and ultrastructura responses to exposure to ultraviolet radiation in the red alga Aglaothamnion uruguayense (WR Taylor). Braz J Bot, 2017; 40(3):783-91. 
Paliwal C, Mitra M, Bhayani K, Bharadwaj SV, Ghosh T, Dubey S, Mishra S. Abiotic stresses as tools for metabolites in microalgae. Bioresour Technol, 2017; 244:1216-26.

Pasquet V, Chérouvrier JR, Farhat F, Thiéry V, Piot JM, Bérard JB, Kaas R, Serive B, Patrice T, Cadoret JP. Study on the microalgal pigments extraction process: performance of microwave assisted extraction. Process Bioch, 2011; 46(1):59-67.

Portwich A, Garcia-Pichel F. A novel prokaryotic UVB photoreceptor in the cyanobacterium Chlorogloeopsis PCC 6912. Photochem Photobiol, 2000; 71(4):493-8.

Puchkova T, Khapchaeva S, Zotov V, Lukyanov A, Solovchenko A. Microalgae as a sustainable source of cosmeceuticals. 2020. Available via Preprints.org

Rastogi RP, Madamwar D, Nakamoto H, Incharoensakdi A. Resilience and self-regulation processes of microalgae under UV radiation stress. J Photochem Photobiol, C, 2020; 43:100322.

Re R, Pellegrini N, Proteggente A, Pannala A, Yang M, RiceEvans C. Antioxidant activity applying an improved ABTS radical cation decolorization assay. Free Radic Biol Med, 1999; 26(9-10):1231-7.

Rojo C, Herrera G, Medina-Sánchez JM, Villar-Argaiz M, Durán C, Carrillo P. Are the small-sized plankton communities of oligotrophic ecosystems resilient to UVR and P pulses? Freshw Sci, 2017; 36(4):760-73.

Roleda MY, Nyberg CD, Wulff A. UVR defense mechanisms in eurytopic and invasive Gracilaria vermiculophylla (Gracilariales, Rhodophyta). Physiol Plant, 2012; 146(2):205-16.

Ruescas A, Pereira-Sandoval M, Tenjo C, Ruiz-Verdú A, Steinmetz F, De Keukelaere, L. Sentinel-2 atmospheric correction intercomparison over two lakes in Spain and Peru-Bolivia. In: Proceedings of the Colour and Light in the Ocean from Earth Observation (CLEO) Workshop, 2016 Sep 6-8, ESA-ESRIN, Frascati, Italy, 2016, pp 6-8. 2016.

Sathasivam R, Radhakrishnan R, Hashem A, Abd Allah EF. Microalgae metabolites: a rich source for food and medicine. Saudi J Biol Sci, 2019; 26(4):709-22.

Sijil PV, Adki VR, Sarada R, Chauhan VS. Stress induced modifications in photosystem II electron transport, oxidative status, and expression pattern of acc D and $\mathrm{rbc} \mathrm{L}$ genes in an oleaginous microalga Desmodesmus sp. Bioresour Technol, 2020; 318:124039.

Singh R, Upadhyay AK, Singh DV, Singh JS, Singh DP. Photosynthetic performance, nutrient status and lipid yield of microalgae Chlorella vulgaris and Chlorococcum humicola under UV-B exposure. CRBIOT, 2019; 1:65-77.

Singleton VL, Rossi JA. Colorimetry of total phenolics with phosphomolybdic-phosphotungstic acid reagents. Am J Enol Vitic, 1965; 16(3):144-58.

Thiyagarasaiyar K, Goh BH, Jeon YJ, Yow YY. Algae metabolites in cosmeceutical: an overview of current applications and challenges. Mar Drugs, 2020; 18(6):323.

Tian J, Yu J. Changes in ultrastructure and responses of antioxidant systems of algae (Dunaliella salina) during acclimation to enhanced ultraviolet-B radiation. J Photochem Photobiol, B, 2009; 97(3):152-60.
Villafañe V, Andrade M, Lairana V, Zaratti F, Helbling E. Inhibition of phytoplankton photosynthesis by solar ultraviolet radiation: studies in Lake Titicaca, Bolivia. Freshw Biol, 1999; 42:215-24.

Villafañe VE, Cabrerizo MJ, Erzinger GS, Bermejo P, Strauch SM, Valiñas MS, Helbling EW. Photosynthesis and growth of temperate and sub-tropical estuarine phytoplankton in a scenario of nutrient enrichment under solar ultraviolet radiation exposure. Estuar Coasts, 2017; 40(3):842-55.

Villafañe VE, Gao K, Helbling EW. Short-and long-term effects of solar ultraviolet radiation on the red algae Porphyridium cruentum (SF Gray) Nägeli. Photochem Photobiol Sci, 2005; 4(4):376-82.

Virtanen O, Valev D, Kruse O, Wobbe L, Tyystjarvi E. Photoinhibition and continuous growth of the wild-type and a high-light tolerant strain of Chlamydomonas reinhardtii. Photosynthetica, 2019; 57(2):617-26.

Wang HMD, Chen CC, Huynh P, Chang JS. Exploring the potential of using algae in cosmetics. Bioresour Technol, 2015; 184:355-62.

Wang L, Pan B, Sheng J, Xu J, Hu Qu. Antioxidant activity of Spirulina platensis extracts by supercritical carbon dioxide extraction. Food Chem, 2007; 105:36-41.

Williamson CE, Neale PJ, Hylander S, Rose KC, Figueroa FL, Robinson SA, Häder DP, Wängberg SÅ, Worrest RC. The interactive effects of stratospheric ozone depletion, UV radiation, and climate change on aquatic ecosystems. Photochem Photobiol Sci, 2019; 18(3):717-46.

Wong C, Chu W, Marchant H, Phang S. Comparing the response of Antarctic, tropical and temperate microalgae to ultraviolet radiation (UVR) stress. J Appl Phycol, 2007; 19(6):689-99.

Xiong F, Lederer F, Lukavský J, Nedbal L. Screening of freshwater algae (Chlorophyta, Chromophyta) for ultraviolet-B sensitivity of the photosynthetic apparatus. J Plant Physiol, 1996; 148(1-2):42-8.

Yarkent Ç, Gürlek C, Oncel SS. Potential of microalgal compounds in trending natural cosmetics: A review. Sustainable Chem Pharm, 2020; 17:100304.

Zamaloa MdC, Tell G. The fossil record of freshwater microalgae Pediastrum Meyen (Chlorophyceae) in southern South America. J Paleolimnol, 2005; 34(4):433-44.

Zanella L, Pertile P, Massironi M, Massironi M, Caviola E, U.S Patent and Trademark Office. Extracts of microalgae and their application U.S. Patent 2019/0117712. 2019-04-25.

How to cite this article:

Tenorio C, Ramírez JAH, Ramos LF, Soto AR, Vargas J. Effects of ultraviolet radiation on production of photoprotective compounds in microalgae of the genus Pediastrum from high Andean areas of Peru. J Appl Pharm Sci, 2022; 12(03): 087-095. 